\title{
Repeated ground-penetrating
} radar measurements to detect

\section{seasonal and annual variations of an englacial conduit network}

\section{Other Conference Item}

Author(s):

Church, Gregory James (1D; Bauder, Andreas (1); Grab, Melchior (1); Schmelzbach, Cédric (1); Maurer, Hansruedi

Publication date:

2020-05

Permanent link:

https://doi.org/10.3929/ethz-b-000461905

Rights / license:

Creative Commons Attribution 4.0 International

Originally published in:

EGUsphere, https://doi.org/10.5194/egusphere-egu2020-19365 
EGU2020-19365

https://doi.org/10.5194/egusphere-egu2020-19365

EGU General Assembly 2020

(c) Author(s) 2021. This work is distributed under

the Creative Commons Attribution 4.0 License.

\title{
Repeated ground-penetrating radar measurements to detect seasonal and annual variations of an englacial conduit network
}

\author{
Gregory Church ${ }^{1,2}$, Andreas Bauder $^{2}$, Melchior Grab ${ }^{1,2}$, Cédric Schmelzbach ${ }^{1}$, and Hansruedi \\ Maurer \\ ${ }^{1}$ ETH Zürich, Institute of Geophysics, Exploration and Environmental Geophysics, Zürich, Switzerland \\ ${ }^{2}$ ETH Zürich, Laboratory of Hydraulics, Hydrology and Glaciology (VAW), Zürich, Switzerland
}

Surface meltwater is routed through the glacier's interior by englacial drainage systems into the subglacial drainage system. The subglacial drainage system plays an important control on the glacier sliding velocity. Therefore, studying the evolution of englacial drainage systems throughout the melt season is key to understanding how these englacial drainage systems develop, and how they subsequently feed the subglacial drainage system.

We have conducted 10 repeated ground-penetrating radar using a Sensor \& Software pulseEKKO Pro GPR system with $25 \mathrm{MHz}$ antenna between 2012 and 2019 over an englacial conduit network, $90 \mathrm{~m}$ below the glacier's surface, on the Rhonegletscher, Switzerland. These repeated measurements allowed insights into both annual and seasonal changes. We were also able to have direct observations into the englacial conduit network from six boreholes that were drilled in August 2018 using a GeoVISION ${ }^{\top M}$ Dual-Scan borehole camera.

The annual results provided evidence that the englacial drainage network developed between 2012 and 2017. The seasonal evolution of the englacial conduit was studied by inverting the GPR data using an impedance inversion. The impedance inversion delivered reflection coefficients, which provides information on the englacial material properties associated with the englacial conduits. The inversion results provide evidence that during the winter season the englacial network is inactive. During June the englacial network becomes active by transporting surface melt water, and it becomes fully active later in the melt season (August). The reflectivity in summer (June-October) is -0.6, indicating the presence of water within the network. In winter (NovemberMay) the reflectivity is around 0 indicating that the system is neither air or water filled and therefore the system physically closes.

The data processing workflow provided a top and bottom reflection coefficient of the conduit. The travel time between the reflection coefficients can be converted to a thickness when using EM wave velocity of water (from 2018 borehole observations). During the summer months the englacial network is around a quarter wavelength thick $(0.3 \mathrm{~m})$, which is approximately the limit of the vertical resolution. 